\title{
IMPORT SUBSTITUTION AND IMPLICIT TAXATION OF AGRICULTURE IN BRAZIL ${ }^{1}$
}

\author{
Eliseu Roberto de Andrade Alves \\ Affonso Celso Pastore
}

The industrialization that Brazil experienced prior to World War II was not induced by the government. It had its origin in the relative profitability of the agricultural and industrial sectors, which favored a shift in resources to the industrial sector. During the period from the end of World War II until the early sixtie; a deliberate import-substitution policy was pursued. The factors that gave rise that policy were the difficulty that the country encountered in foreign trade during the Depression and the two world wars, the influence of the Prebish thesis, and the dominance of two sector models (Rannis \& Fei 1961 and Jorgenson 1969) as the basis for development policies.

Brazilian industrialization policy was based upon three principles: protection against international competition, easy access to capital, and stable wages. This constituted a policy to transfer resources generated in agriculture to industry, thus penalizing the primary sector.

The period after World War II witnessed an industrial growth never before seen in Brazilian history. Industrialization generated strong pressures for urbanization, with the result that, by $1970,56 \%$ of the population was urban. This created pressures on the supply of food and fibers.

1 Reprinted with permission and minor changes from "American Journal of Agricultural Economics", 60(5):865-71, Dec. 1978. 
This paper attempts to review some effects of industrialization on agriculture. It concentrates on economic and trade policies that resulted in the implicit or explicit taxation of agriculture.

\section{Brazilian Trade Policies, 1946-77}

This section draws heavily upon studies by Martin (1976), Melo ¿ 2 Zockun (1977) and Veiga (1974), where a detailed description of the various trade policies may be found. The import policies were designed to stimulate industrialization by protecting the industrial sector against foreign competition and by reducing the cost of capital. These policies also aimed at controlling imports to solve the problem of recurrent trade deficits.

Export policy was based on an "exportable surplus" model (Leff 1969). Trade policy in the period that extended from the end of World War II to 1964 was characterized by a strong bias against exports, thereby discriminating heavily against agriculture. After 1964 most export controls were eliminated and discrimination against exports was reduced substantially in respect to industrial products. In 1968 export promotion policies were established to stimulate the exports of industrial products. The benefits of such policies for agricultural products were small. Moreover, in the case of some agricultural products, outright export prohibition continued when government authorities believed agricultural prices were rising "too rapidly" and/or that "scarcity" could occur in the domestic market.

Trade policies during this period provided strong protection to industry. Bergsman \& Candal (1969) indicate that effective protection was $190 \%$ for consumption goods, $50 \%$ for intermediate goods, and $15 \%$ for capital goods. The effective protection for agriculture, on the other hand, was negative. Moreover, in the period 1954-59 the effective exchange rate for imports varied from 2.4 to 4.0 times the effective exchange rate for exports.

The result of these policies was the transference of a substantial amount of resources from agriculture to industry. Fishlow (1967) estimates the amount transferred from agriculture to vary from $2.1 \%$ to $7.3 \%$ of industrial gross national product (GNP) in the period $1955-57$, and to range from $11.6 \%$ to $19.1 \%$ in the period 1958-60.

Trade policy was modified several times in the period 1946-64. Quantitative controls to restrict imports prevailed from 1947 to 1954 . Multiple exchange rates for exports were established in the period 1953-57. Ad valorem tariffs were 
introduced in 1957, and substantially increased the protection provided industry. For the general category of imports these tariffs could reach $80 \%$ of the value of the good. For the specific category they could be as high as $150 \%$, with further increases permitted by an exchange rate charge that varied from $100 \%$ to $200 \%$.

In the period 1964-67, an effort was made to simplify the trade regulations and to open the economy to international markets. The external debt was refinanced, the government tried to keep imports to a minimum, it started to encourage exports, and it began efforts to fight the serious domestic inflation. Means of encouraging exports consisted not only of more frequent devaluations of the cruzeiro but also of some reductions in the "contribution quotas" made by coffee and cocoa exporters. However, in January 1965, a 30\% "contribution quota" was placed on beef exports. Ad valorem tariffs on some export commodities were reduced, however.

Policies initiated in the previous period were carried over into the 1967-73 period. Continued efforts were made to reduce trade distortions. Tariffs were reduced, exchange rates were further unified, and the multiple exchange rates were eliminated.

The major new policy innovation was the introduction of the floating peg exchange rate system. This consisted of frequent "minidevaluations" that occurred seven to eight times per year. These were at first made at regular intervals, but later they were randomized to discourage exchange market speculation. The basic rule followed was to devalue the cruzeiro at a rate approximately equal to the difference between Brazil's internal inflation and the average inflation of Brazil's major trading partners, predominantly the United States, Western Europe, and Japan.

Moșt export controls were eliminated, although some controls were maintained on coffee and cocoa. Various fiscal, credit and exchange rate policies were used to provide incentives to export, although these were directed more to the industrial sector than to the agricultural sector. The government provided special incentives to stimulate exports by private firms, such as exemption from excise taxes on all exports, exemption from sales taxes on certain products used in production for export, exemption of export earnings from income tax or reduction of such tax, credit to finance export sales and export promotion at overseas trade exhibitions.

Bacha and colleagues estimate that the cruzeiro was overvalued from $20 \%$ to $25 \%$ in the early to mid-1960s. Pastore et al. (1976b) estimated that the exchange 
rate that would bring equilibrium to the balance of commerce was close to the observed rate for the period 1970-73. This suggests the elimination of part of the trade distortions brought about by changes in trade policies in the period 1964-73.

Oil prices increased fourfold in October 1973. Aftex six years of positive results for the balance of payments, with a surplus of US $\$ 1.6$ billion in 1973, a substantital deficit of US\$938 million occurred in 1974 . The choice made by the government to curb the crisis in the balance of commerce was to reintroduce import controls. The ad valorem tariffs were raised, and outright prohibition on items and other measures to reduce imports were imposed. The cruzeiro became overvalued again and preliminary estimates reported by Rosa (1978) place the rate of overvaluation between $25 \%$ and $35 \%$. The rate of inflation rose to $40 \%$, and price controls on agricultural products became frequent again. The export policy for industrial products was carried over, with minor modifications, into the period 1973-77.

\section{Trade Policies and the Distribution of Income}

One consequence of the trade policies was to reduce the cost of capital to industry. At the same time, wage policy raised the private cost of labor well above its social cost (Bacha et al. 1971). The combination of cheap capital and high-cost labor caused the industrial sector to have a low absorptive capacity for labor. In 1964, the industrial sector accounted for $35 \%$ of GNP while the share in employment was only about $8 \%$. This was far below the comparative share in other countries with a similar degree of industrialization (Bergsman \& Candal 1969).

The low capacity of the industrial sector to absorb labor caused labor to be dammed up in agriculture, with the result that a large flow of rural-urban migrants was channeled into the low productivity service sector or accumulated as urban unemployed. The average productivity of labor in industry, which in 1950 was 6.4 times greater than the average productivity of labor in agriculture, increased to 11.6 times in 1970. In a sense this indicates a worsening in the distribution of income between the two sectors.

The link between trade strategies and employment is complex. According to Krueger (1978), "it involves not only trade strategies themselves and the structure of the labor market but also entails examination of various factors which contribute to distorting goods and factor markets" (p. 270). Three linkages which hold simultaneously can be identified. First, there is the effect of the trade strategy on the overall rate of growth and in turn on the rate of growth of employment 
opportunities. In the case of Brazil, Valderrama (1976) has studied the impact of the export subsidies for industrial products on the growth of the economy and the growth of exports. His results do not support the idea that the subsidies for industrial products fostered either the growth of the economy or the growth of exports.

A second linkage is the effect on the demand for labor via the influence of the trade strategy on the composition of output. If a trade strategy results in a higher proportion of GNP originating in labor-intensive industries, the selection of the strategy will result unequivocally in a higher demand for labor (at a given real wage) than will the selection of the alternative. The third linkage is the effect that the trade regime has on factor prices. To the extent that trade policy results in incentives for the use of capital-intensive techniques, it affects the demand for labor.

The trade strategies of 1946-73 discriminated severely against agriculture. To the extent that agriculture is more labor-intensive than industry, trade policy reduced the overall demand for labor, other things being equal. Data provided by Barros (1973) suggest that the export promotion strategies benefited relatively more those industries with a high capital-output ratio and which also require labor with a high level of training and specialization. This led to an increase in the demand for a type of labor that was in short supply, and hence contributed to a worsening in the distribution of income (Langoni 1973).

The overvalued exchange rate and selected export subsidies also distorted internal prices. Pastore (1967) conclude that elimination of these distortions would raise the relative price of products consumed by the poor. At the same time, the price of products consumed by the rich would decline. Hence, correction of the distortions would aggravate the distribution of income problem, at least in the short run.

A similar point has been made by Schuh (1977) in respect to agricultural products. If export restrictions were eliminated the shortrun effect would be an increase in agricultural prices, to the detriment of low income groups. The effect on the rich would be weaker since the consumption of food is a small share of their total consumption.

Trade policy also had a number of effects that were detrimental to regions outside of the industrial Southeast. First, these regions were forced to pay higher prices for those consumption and capital goods produced behind the protective tariff wall than they would have paid if they had been able to import them at 
nondistorted prices. Second, capital which could have been invested in their own development was transferred out of these regions by means of trade policy. The loss of capital meant that the capital-supplying regions could not provide additional employment for their population, nor finance needed improvements in their basic infrastructure such as education, roads, or agricultural research and extension activities. From about 1950 until 1961 the Northeast experienced an average annual transfer of capital to São Paulo of about US\$ 25 million. For the entire country outside of the State of São Paulo the transfer to this state was about US\$ 31 million (Martin 1976).

Starting in 1962, the resource flow among regions through the terms of trade reversed. The factors affecting this reverse flow included the trade reforms starting in 1964, the rise in international commodity prices (in 1969), and government programs designed to help the Northeast.

\section{Trade Policies and Productivity Growth in Agriculture}

Trade policy had a positive effect on agriculture by means of the large urban-industrial complexes that arose as a consequence of import-substituting industrialization. Agriculture benefited from the expansion of the nonfarm labor market which increased the number and kinds of jobs a available to prospective migrants. This speeded up the migration process, and as the opportunity cost of labor increased, a reorganization of agriculture was induced. The market for agricultural commodities became large and predominantly located at a few growth poles. Agriculture located close to these poles could operate at lower average cost-either because of increased specialization or because of the realization of economies of scale. With the concentration of production, more social-overhead capital was provided. This included roads, which lowered transportation costs, and improved educational facilities, which increased labor mobility and raised labor productivity (Schuh, 1969).

Recent literature stresses the role of periodic food supply crises on policy making (Smith 1969). The urban-industrial complexes were very sensitive to food shortages and hence were an instrument of pressure on the government to shape an agriculture policy that would increase the production of agricultural commodities at a lower cost. In the short run, the signs of crisis were frequently misinterpreted. Price and export controls were established for agricultural products to lower or to restrain the price increases. But the crises eventually brought about a change in policy, with greater emphasis on increasing agricultural productivity. 
The negative effects of trade policies are related to the participation of agriculture in international trade. This participation could have been larger if it were not for the restrictions that stemmed from an overvalued currency and in certain cases from outright prohibitions against the export of agricultural products. The negative effects also are related to the fact that agriculture could have had access to lower-priced inputs if it were not for the protection given to the industrial sector. The increase in price for modern inputs was a severe restriction to the modernization of agriculture.

Barros $\propto$ Graham (1978) recently constructed aggregate indices for production and productivity of Brazilian agriculture. They considered two regions and compared them with the State of São Paulo. The results were also aggregated for all of Brazil. One region was the poverty-stricken and densely populated Northeast, while the second region included all other states except São Paulo, the Northeast, and the North region (the Center-South). The two regions and the State of São Paulo combined account for about $90 \%$ of the agricultural output of the country.

Two classes of products were considered: one included products for the domestic market and the other products for foreign markets. At the aggregate level the annual rate of increase of production for domestic products was $4.4 \%$ for the period $1932-76,4.0 \%$ for the period $1962-76$, and $3.3 \%$ for the period $1968-76$. On the other hand, if one excludes coffee from the export products, the annual rates of increase of production for this class of products were $5.3 \%$ for the period $1932-76,7.2 \%$ for the period $1962-76$, and $9.8 \%$ for the period $1968-76$. When coffee was included among the export products, the annual rates of growth for this class of products declined to $4.4 \%$ for the period $1932-76$, to $4.0 \%$ for the period $1962-76$, and, finally, to $3.3 \%$ for the period $1968-76$.

Given that population was growing at a rate of $2.7 \%$ per year, per capita income was increasing at a rate of $6.0 \%$ per year, and assuming an income elasticity of demand of $\mathbf{0 . 5}$, it appears that domestic demand was increasing at a rate of $6.0 \%$ per year. Hence, although the aggregate rates of growth of production were greater than the rate of increase of population, they were not keeping pace with the increase in demand. This was reflected in an upward trend in agricultural prices in recent times. Moreover, products for the domestic markets were being replaced at the production level by export products. This probably aggravated the nutritional problems of the low-income classes. Turning to the productivity of land, in São Paulo the productivity for export products (with coffee) increased at a rate of $8.1 \%$ per year for the period $1962-76$ and $12.6 \%$ for the period $1968-76$. If coffee 
is excluded from the export products, there was no increase in land productivity in the period 1968-76, although the increase was at an annual rate of $5.0 \%$ in the period 1962-76. Productivity of land for domestic products increased at a rate of $5.3 \%$ and $8.0 \%$, respectively, for the periods $1962-76$ and $1968-76$.

Coffee is not an important product in the Northeast region. The rates of growth of productivity for the export products were $2.5 \%$ in the period $1962-76$ and $4.0 \%$ in the period $1968-76$. There was no increase in the productivity of land for domestic products in the period 1962-76, while for the 1968-76 period there was actually a decline in productivity (at a rate of $4.5 \%$ per year).

In the Center-South region there was no change in the productivity of land dedicated to export products for either period. If coffee is excluded from the index, the productivity of land for export products increased at an annual rate of $3.4 \%$ for the period 1962-76, but there was no increase for the 1968-76 period. The rate of increase of productivity for domestic products for the period 1962-76 was $1.6 \%$. Again, no increase was observed for the $1968-76$ period.

For purposes of analysis, two questions can be posed: Why were the observed rates of increase of productivity higher in São Paulo than in other regions, and why was the performance of agriculture in general relatively modest? The answers can be found in the Janvry (1973), which puts the emphasis on stress, synonymous with falling profits. This idea can be used to further clarify the role of the urban industrial complexes in the modernization of agriculture. But in the case of Brazil, stress is a consequence of increases in the price of food for the urban sector and of the need to expand exports so as to pay for a growing demand for imports brought about by industrialization. The urban population is very sensitive to food shortages and has considerable capacity to influence government to modify agricultural policy so as to increase the supply of food.

To respond to the first question, it is clear that the agriculture located closer to urban industrial complexes can obtain more benefits from them than the agriculture which is farther away. The benefits would come as a consequence of agglomeration, and of agricultural policy on the part of both the federal and state governments that is best designed to avoid a shortage of food and to foster the production of export products. To exemplify, it is well known that São Paulo has invested much more in research and extension than the other states (Smith 1969).

The distortions created by the trade policies also helped São Paulo to develop its extension and research institutions because the state benefited from a substantial 
resource flow from the rest of the country. The agriculture of the State of São Paulo also benefited from the fact that its urban-industrial complexes were developed earlier than in the other states. Martin has shown that the level of urban industrial development plays an important role in explaining why some states invested more than others in these activities.

Martin (1976) drew on previous works by Thompson (1974) to calculate the internal rate of return that would be realized if the states taken together were to invest in research and extension in the same proportion as São Paulo. Two experiments were performed. The first one maintained for the rest of Brazil (the aggregate of the other states) the same ratio of technicians per 10,000 rural workers as for São Paulo. This would have required that the other states taken together would have had to employ 31,675 technicians. They were in fact employing only 8,189 technicians in 1970, as compared to São Paulo's 2,978 technicians. The other experiment maintained for the rest of the country the same ratio of technicians per $\operatorname{Cr} \$ 10,000$ of value of agricultural production. In this case the other states taken together would have employed 11,133 technicians. The internal rate of return was $18 \%$ for the first experiment and $28 \%$ for the second, both of which compare well with the $20 \%$ rate of return found for the State of São Paulo.

The second question is addressed to the rather modest performance of the agricultural sector. The literature on this subject is extensive, but it can be reduced to three lines of thought. The first was popular in the early 1960 s and gave a great deal of emphasis to the size distribution of land. The basic proposition that stems from it is agrarian reform (Cline 1970). The second line of thought is in the neoclassical tradition and considers the industrialization policies - trade distortions, price and export controls, etc. as negatively affecting the modernization of agriculture (Schuh 1974). The Hayami \& Ruttan (1971) book inspired the third line of thought: the abundance of land and labor that prevailed during a long period of Brazilian history acted as a brake on the modernization of agriculture, leading to agricultural policies strongly biased toward an increase of cultivated area as opposed to an increase of productivity (Pastore et al. 1976a, Schuh 1974).

The overvaluation of the currency is an implicit tax on the agricultural sector. The predicted effects of this tax indicate a reduction in the use of land, labor, and capital, and a transfer of resources to the urban sectors. These negative effects were aggravated by the fact that the industrialization policies increased the prices of modern inputs; hence the trade policies subjected agriculture to a double squeeze, decreasing the price of agricultural products and increasing the costs of production. There were some compensating measures through subsidies in the form of cheap credit, but these measures led to still further distortions. 
Lopes (1977) built an econometric model to evaluate the consequences of an overvaluated currency on the agricultural sector. Using a partial equilibrium model he tried to detect the effects of a 10 percent decrease in the prices of agricultural products. His main conclusions are:

1. Decrease in Farm Labor - There would be an approximate 18 percent decrease in the level of use of labor in agriculture Among small farmers (less than 10 hectares) only 3 to 4 percent of the labor force would have to leave the sector. Among medium size farmers ( 10 to 500 hectares) between 22 and 26 percent of the labor force mostly landless workers, would be transferred. Among the large farmers (larger than 500 hectares), some 32 to 34 percent of the labor force would have to leave.

2. Decrease of Marginal Value of Labor - The value of the marginal product of labor in agriculture would decrease by approximately 15 percent. When this is combined with the overvaluation of labor in the industrial sector due to its protection, one begins to understand the large income differential that has emerged between the industrial and agricultural sector in Brazil.

3. Transfer of Capital - There would be a release of about 27 percent of the mobile capital for investment in the non-farm sector. The transfer of capital would be relatively larger among the large farms where between 36 to 43 percent of the capital would transfered as compared to the middle size farms that would transfer between 23 to 26 percent of their capital.

4. Decrease of Land Use - Some 7 to 11 percent of land would be withdrawn from production among the middle size farms and between 15 to 16 percent among the large farms.

Based on this result, one can argue that if a more appropriate exchange rate policy were pursued, Brazil might have 15 percent more area under cultivation. These findings help to explain the under-utilization of land that is common in Brazil, the reason why land in large holdings tends to be more under-utilized than land of small farms and the lack of strong incentives for farmers to use land-saving technology. Hence in a real sense, trade policies were detrimental to the modernization of agriculture.

\section{CONCLUSION}

The rapid industrialization of Brazil succeeded in changing its product mix in 
a short period of time. An urban-industrial complex was created, which in 1975 already accounted for $89.5 \%$ of national income. Moreover, $62 \%$ of the population was living in the cities (Fundação IBGE 1976). Growth rates were very high in the 1965-76 period, with GNP per capita growing 6.2\% per year and total GNP increasing at a rate of $9.2 \%$ per year (Conjuntura Econômica 1977 ).

There is growing concern on the part of commercial partners of Brazil in relation to her present trade policies. This concern will probably induce changes that will benefit the exports of products originating in agriculture and those that have high labor content. However, increased per capita income, a high rate of population growth and urbanization, and the need to export more every year will result in accelerating demand for food and fiber from Brazil's agricultural sector. A food crisis will emerge unless production shows a major increase, and the results reported herein suggest that the supply of food and fibers is probably lagging behind the growth of demand.

Brazil in the past could count on an agricultural frontier with favorable ecological conditions. The remaining frontier has continental size, but is far removed from population centers and requires huge capital investments in infrastructure. It also needs large investiments in research and development of new agricultural technology which up to now have not been produced in other countries or other areas of Brazil.

\section{REFERENCES}

BACHA, A.B. de A.; MATA, M. de \& MODENESI, R.L. Análise governamental de projetos de investimentos no Brasil: procedimentos e recomendações. s.I., IPEA/INPES, 1971. (IPEA/INPES. Relatório, 1 ).

BARROS, J.R.M. de. Exportações agrícolas não-tradicionais e o custo doméstico das divisas. Est. Econ., 3: 7-30, 1973.

BARROS, J.R.M. de \& GRAHAM, D.H. A agricultura brasileira e o problema da produção de alimentos. São Paulo, IPE/USP, 1978. Trabalho apresentado no Seminário sobre Economia e Tecnologia.

BARROS, J.R.M. de et alii. Sistema fiscal e incentivos às exportações. R. bras. Econ., (4): 3-24, 1975.

BERGSMAN, J. Brazil: industrialization and trade policies. London, Oxford University Press, 1971. 
BERGSMAN, J. \& CANDAL, A. Industrialization, past sucess and future problems. In: ELLIS, H.S., ed. The economy of Brazil. Barkeley, University of California Press, 1969.

CLINE, W.R. Economic consequences of land reform in Brazil. Amsterdam, North-Holland Publishina Co., 1970.

CONJUNTURA ECONÔMICA. Rio de Janeiro, v.31, n.6, 1977.

DE JANVRY, A. A socioeconomic model of induced innovations for argentine agricultural development. Quart. J. Econ., 87(3): 410-35, 1973.

FISHLOW, A. Foreign trade regimes and economic development. NBER, 196\%. (Soecial Conference Series on Foreian Trade Regimes and Economic Development). Mimeografado.

FUNDAÇÃo IBGE, Rio de Janeiro, RJ. Anuário estatístico do Brasil - 1976. Rio de Janeiro, 1976.

HAYAMI, Y. \& RUTTAN, V.W. Agricultural development: an international perspective. Baltimore, J. Hopkins University Press, 1971.

JORGENSON, D.W. The role of agriculture in economic development: classical versus newclassical modes of growth. In: WHARTON JUNIOR, C.R., ed. Subsistence agriculture and economic development. Chicago, Aldine Publishing Co., 1969.

KRUEGER, A.O. Alternative trade strateaies and employment in LDCs. Amer. Econ. Rev., 68: $270-4,1978$.

LANGONI, C.G. Distribuição da renda e desenvolvimento econômico do Brasil. Rio de Janeiro, Expressão e Cultura, 1973.

LEFF; N. The exportable surplus approach to foreign trade in under developed countries. Econ. Develop. Cultur. Change, 17:346-55, 1969.

LOPES, M. de R. The modernization of resources from agriculture: a policy analysis for Brazil. Purdue University, 1977. Ph.D. thesis.

MARTIN, M.A. Modernization of brazilian agriculture: an analysis of unbalanced development. Purdue University, 1976. Ph.D. thesis.

MELO, F.B.H. de \& ZOCKUN, M.H.G.P. Exportações agrícolas, balanço de paaamentos e abastecimento do mercado interno. Est. Econ., 7:7-50, 1977.

PASTORE, A.C. Exportações agrícolas e desenvolvimento econômico. Versão preliminar. Rio de Janeiro, Fundacão Centro de Estudos do Comércio Exterior, 1967. Mimeografado.

PASTORE, A.C.; ALVES, E.R. de A. \& RIZZIERI, J.A.B. A inovação induzida e os limites à modernização na agricultura brasileira. R. Econ. rural, 14:257-85, 1976a. 
PASTORE, A.C.; BARROS, J.R.M. de \& KADOTA, D. A teoria da paridade do poder de compra, mini desvalorizações e equilíbrio da balança comercial brasileira. Pesq. e Planej. Econ., (2) : 287.312, $1976 \mathrm{~b}$.

PREBISH, R. O desenvolvimento econômico da América Latina e seus principais problemas. R. bras. Econ., 3: 47-111, 1949.

RANNIS, G. \& FEI, J.C. A theory of economic development. Amer. Econ. Rev., 51:533-65, 1961.

ROSA, J. de A. Análise da evolução estrutural e geográfica das exportações brasileiras. Versão preliminar. Rio de Janeiro, Fundação Centro de Estudos do Comércio Exterior, 1978. Mimeografado.

SCHUH, G.E. Comment. In: THORBECKE, E. The role of agriculture in economic development. New York, Columbia University Press, 1969.

SCHUH, G.E. A modernização da agricultura brasileira. In: ALTERNATIVAS de desenvolvimento para grupos de baixa renda na agricultura brasileira. São Paulo, IPE/USP, 1974. v.2.

SCHUH, G.E. A política cambial e o desenvolvimento da agricultura no Brasil. R. Econ. rural, 3: 3-56, 1977.

SMITH, G.W. Brazilian agriculture policy - 1950-67. In: ELLIS, H.S. The economy of Brazil. Berkeley, University of California Press, 1969.

THOMPSON, R.L. The meta production function for brazilian agriculture: an analysis of productivity and other aspects of agricultural growth. Purdue University, 1974. Ph.D. Thesis.

VALDERRAMA, V.F.P. Export incentive policies and economic development in Brazil. Ohio State University, 1976. Ph.D. Thesis.

VEIGA, A. The impact of trade policy on brazilian agriculture, 1947-67. Purdue University, 1974. PhD. Thesis. 